\title{
Chest X Ray Examination of Aspirated Peanut in Children: Is it Important ?
}

\author{
Efiaty Arsyad Soepardi
}

\begin{abstract}
Abstrak
Metode diagnostik yang akurat untuk menegakkan diagnosis aspirasi kacang pada anak sangat diperlukan bagi ahli THT. Telah dilakukan suatu penelitian retrospekt if untuk menilai peranan pemeriksaan foto toraks sebelum tindakan bronkoskopi dilakukan. Tujuan penelitian ini adalah untuk menentukan sensitivitas dan spesifisitas pemeriksaan foto toraks sebelum dan sesudah 24 jam teraspirasi kacang yang dikonfirmasikan dengan adanya kacang yang terlihat waktu bronkoskopi. Delapan puluh sembilan penderita aspirasi kascang datang ke Bagian THT FKUI, Jakarta, dari bulan Januari 1986 sampai dengan Desember 1996. Usia mereka berkisar antara 3 sampai 58 bulan. Pemeriksaan foto toraks tidak dilakukan pada 5 penderita karena adanya gawat napas pada 3 kasus dan 2 penderita menolak untuk dilakukan tindakan bronkoskopi, oleh karena itu tak diikutkan dalam penelitian ini. Analisis statistik menunjukkan bahwa sensitivitas pemeriksaan foto toraks $53,1 \%$, spesifisitas $33,3 \%$, nilai dugaan positif $95,6 \%$ dan nilai dugaan negatif $2,6 \%$.
\end{abstract}

\begin{abstract}
An accurate method of detecting peanut aspiration in children's tracheobronchial tree, is very important to otolaryngologist. A retrospective study to analyze the role of chest X-ray examination as a diagnostic test before bronchoscopy was conducted. The objective of this study is to determine the sensitivity and specificity of plain chest X-ray examination in diagnosing peanut aspiration which was confirmed by bronchoscopy, before and after $\mathbf{2 4}$ hours of aspiration. Eighty nine cases of aspirated peanut in children were found during 11 years period, from January 1986 to December 1996, in the Department of Otorhinolaryngology, Faculty of Medicine, University of Indonesia, Jakarta. Their ages varied from 3 to 58 months. Chest X-ray was not performed in 5 patients because of violate respiratory distress in 3 patients and 2 patients refused the bronchoscopy procedure, therefore they were excluded from the investigation. Statistical analysis revealed that the sensitivity of chest $\mathrm{X}$-ray examination was $53.1 \%$, the specificity was $33.3 \%$, the positive predictive value was $95.6 \%$ and the negative predictive value was $2.6 \%$.
\end{abstract}

Keywords: Aspiration, bronchoscopy

The diagnosis of peanut aspiration in children is still a big problem for otorhinolaryngologist. The children themselves could not give an exact historical review and the symptoms of respiratory obstruction might be disappeared when they arrived at the hospital. Peanut itself is a radioluscent foreign body, and can not be detected by radiological examination while the bronchoscopy is an invasive diagnostic procedure. Since the peanut can occlude the airway suddenly, early diagnosis and prompt treatment is mandatory. A long-period obstruction due to it might cause edema of the mucosa and constriction of the lumen of the tracheobronchial tree, and then followed by lung complication.

Department of Otorhinolaryngology, Faculty of Medicine, University of Indonesia/Dr. Cipto Mangunkusumo Hospital, Jakarta, Indonesia
The objective of this study is to determine the sensitiviy and specificity of chest $\mathrm{X}$-ray as a diagnostic tool in aspirated peanut before and after 24 hours of aspiration and to asses the diagnostic accuracy of a peanut in the airway by comparing plain chest $\mathrm{X}$-ray and bronchoscopy findings. Both procedures are evaluated in the first, second and third day of aspiration.

\section{METHODS}

A retrospective study analyzed the role of plain chest $\mathrm{X}$-ray as a diagnostic test in suspected aspirated peanut in the tracheobronchial tree. The medical records containing the patient's identity, the history of peanut aspiration, the physical examination including signs and symptoms, otorhinolaryngological examination, and radiological and bronchoscopy findings were reviewed. Time interval between aspiration and the radiological examination in all patients were 
recorded. Since peanut is a radioluscent foreign body, it can not be detected in radiological examination; hence the search of the subsequent result i.e. lung complication such as atelectasis, emphysema, infiltrate or pneumonia was conducted by a radiologist. Radiological examination was classified as positive if there was lung complication caused by the lodging of peanut in the tracheobronchial tree, and negative if the lung was normal. Positive bronchoscopy meant that there was a peanut in the tracheobronchial tree and negative if it was not found on bronchoscopy. Eighty nine cases were found during 11 years, between January 1986 to December 1996 in our institution. Chest X-ray and bronchoscopy procedures were performed in only 84 cases. Three patients underwent bronchoscopy without prior chest $\mathrm{X}$-ray because of violate respiratory distress and 2 patients refused bronchoscopy procedure, hence they were excluded from this investigation. In the 84 cases the chest X-ray was done on admission at the Department of Radiology, and the bronchoscopy was performed by using a rigid bronchoscope under general aenesthesia by otorhinolaringologist.

\section{RESULTS}

Eighty four patients which meet the criteria of this study were analyzed. They were 45 boys $(53.6 \%)$ and 39 girls $(46.4 \%)$, thus the sex ratio was $1.1: 1$. These patients' age ranged from 3 to 58 months, with the mean age of 28.3 months.

Fifty four patients $(64.3 \%)$ came in the first 24 hours (0-24 hours), 11 patients (13.1\%) in the second 24 hours ( 25 up to 48 hours), 8 patients (9.5\%) in the third 24 hours (49 up to 72 hours) and the rest 11 patients (13.1\%) came after 72 hours of aspiration (Table 1 ).

The radiological examination revealed positive result in 45 patients $(53.7 \%)$ and negative result in 39 patients (46.3\%) (Table 2).

Bronchoscopy which was carried out in all patients indicate the position of the peanut, however in 3 patients the peanut was not found in the tracheobronchial tree (Table 3).

Table 4 shows the correlation between chest $X$-ray and bronchoscopy findings in 84 patients. True positive was found in 43 patients, false positive in 2 patients, true negative in 1 patient and false negative in 38 patients. Diagnostic test analysis revealed that the sensitivity of chest $\mathrm{X}$-ray examination compared with bronchoscopy investigation as a gold standard was $53.1 \%$, the specificity was $33.3 \%$, positive predictive value was $95.6 \%$ and negative predictive value was $2.6 \%$.

Table 1. Length of time between aspiration and chest X-ray

\begin{tabular}{lrr}
\hline \multirow{2}{*}{ Length of Time } & \multicolumn{2}{c}{ Cases } \\
\cline { 2 - 3 } & \multicolumn{1}{c}{$\mathrm{n}$} & $\%$ \\
\hline$<24 \mathrm{~h}$ & 54 & 64.3 \\
$25-48 \mathrm{~h}$ & 11 & 13.1 \\
$49-72 \mathrm{~h}$ & 8 & 9.5 \\
$>72 \mathrm{~h}$ & 11 & 13.1 \\
\hline Total & 84 & 100.0 \\
\hline
\end{tabular}

Table 2. Chest X-ray in 84 patients

\begin{tabular}{lrr}
\hline \multirow{2}{*}{ Chest X-ray } & \multicolumn{2}{c}{ Cases } \\
\cline { 2 - 3 } & $\mathrm{n}$ & $\%$ \\
\hline Positive & & \\
- Atelectasis & 13 & 15.5 \\
- Emphysema & 26 & 31.0 \\
- Infiltrate & 1 & 1.2 \\
- Pneumonia & 5 & 6.0 \\
Negative & 39 & 46.3 \\
\hline Total & 84 & 100.0 \\
\hline
\end{tabular}

Table 3. The lodgement of aspirated peanut

\begin{tabular}{lccrr}
\hline \multirow{2}{*}{ Site } & \multicolumn{2}{c}{ Number of cases } & \multicolumn{2}{c}{ Total } \\
\cline { 2 - 5 } & $\begin{array}{c}\text { Before } \\
\text { 24 hours }\end{array}$ & $\begin{array}{c}\text { After } \\
\text { 24 hours }\end{array}$ & n & $\%$ \\
\hline larynx & 3 & 0 & 3 & 3.6 \\
trachea & 27 & 0 & 27 & 32.1 \\
carina & 7 & 0 & 7 & 8.3 \\
left main bronchus & 7 & 13 & 20 & 23.8 \\
right main bronchus & 9 & 15 & 24 & 28.6 \\
not available & 1 & 2 & 3 & 3.6 \\
\hline Total & 54 & 30 & 84 & 100.0 \\
\hline
\end{tabular}

Table 4. The correlation between chest X-ray and bronchoscopy findings in 84 patients

\begin{tabular}{lccc}
\hline \multirow{2}{*}{ Chest X-ray finding } & \multicolumn{2}{c}{ Bronchoscopy findings } & \multirow{2}{*}{ Total } \\
\cline { 2 - 3 } & Positive & Negative & \\
\hline Positive & 43 & 2 & 45 \\
Negative & 38 & 1 & 39 \\
\hline Total & 81 & 3 & 84 \\
\hline
\end{tabular}


Table 5 shows the 54 patients that came in the first 24 hours. Of those cases chest $\mathrm{X}$-ray revealed 17 positive and 37 negative findings; on the other hand bronchoscopy resulted in 53 positive findings and 1 negative finding. Analysis of diagnostic test in the first 24 hours revealed that the sensitivity of chest $\mathrm{X}$-ray was $30.2 \%$, specificity was $0 \%$, positive predictive value was $94.1 \%$ and negative predictive value was $0 \%$. In the thirty patients who came after 24 hours of aspiration, the chest X-ray examination results were positive in 28 patients and negative in 2 patients. Bronchoscopy results were positive in 28 patients and negative in 2 patients. Diagnostic analysis revealed that the sensitivity of chest X-ray after 24 hours of aspiration was $92.9 \%$, specificity was $0 \%$, positive predictive value was $92.9 \%$ and negative predictive value was $0 \%$.

Table 6 shows the correlation between chest X-ray and bronchoscopy findings, and the lodgment duration of a peanut in the tracheobronchial tree. Chest X-ray of the 11 patients that came in 25 up to 48 hours after aspiration was 9 positive and 2 negative, and bronchoscopy findings showed 11 positive and none was negative. Sensitivity of chest X-ray in 25-48 hours after the lodgement of a peanut was $81.8 \%$. Chest X-ray results of the 8 patients that came in 49 to 72 hours after aspiration was 8 positive and none was negative, and bronchoscopy showed 7 positive and 1 negative. Sen- sitivity of a chest X-ray in 49-72 hours after the lodgement of a peanut was $100 \%$. Eleven patients who came after 72 hours after aspiration, the chest X-ray showed 11 positive findings and none was negative, while on bronchoscopy 10 was positive and 1 was negative. Chest X-ray sensitivity after 72 hours of the lodgement of a peanut was $100 \%$. The sensitivity of chest X-ray in the first day was $30.2 \%$, the second day was $81.8 \%$, the third day was $100 \%$ and after 72 hours was $100 \%$.

\section{DISCUSSION}

Peanut apiration cases are the most frequent case of all foreign body aspiration in children. ${ }^{1,2,3,4} \mathrm{~A}$ peanut has a high concentration of fat and is hygroscopic, therefore its lodgement in the tracheobronchial tree will cause mucosal edema and the airway can be occluded in a short time. A peanut in the larynx and trachea usually can occlude the airway directly and respiratory distress can occur suddenly. However, a peanut in carina will cause lung complication in the affected side after several days. Therefore, the radiographic examination may be misleading if it is normal. The peanut may not produce sufficient obstruction, or the obstructive phase may not have developed. Frequently only obstruction of a segmen of lung is demonstrated, because the peanut causes enough reaction to occlude a branch of the tracheobronchial tree.

Table 5. Chest X-ray and bronchoscopy findings before and after 24 hours of aspiration

\begin{tabular}{lcccc}
\hline & \multicolumn{4}{c}{ Bronchoscopy findings } \\
\cline { 2 - 5 } Chest X-ray findings & \multicolumn{2}{c}{ Before 24 hours } & \multicolumn{2}{c}{ After 24 hours } \\
\cline { 2 - 5 } & $\mathrm{n}(+)$ & $\mathrm{n}(-)$ & 26 & $\mathrm{n}(+)$ \\
\hline Positive & 16 & 1 & 2 & 2 \\
Negative & 37 & 0 & 28 & 2 \\
\hline Total & 53 & 1 & &
\end{tabular}

Table 6 . The correlation between chest X-ray, and bronchoscopy findings, and the lodgement duration of peanuts

\begin{tabular}{|c|c|c|c|c|c|c|c|c|}
\hline \multirow{3}{*}{ Chest X-ray findings } & \multicolumn{8}{|c|}{ Bronchoscopy findings } \\
\hline & \multicolumn{2}{|c|}{$0-24 \mathrm{~h}$} & \multicolumn{2}{|c|}{$25-48 h$} & \multicolumn{2}{|c|}{$49-72 h$} & \multicolumn{2}{|c|}{$>72 \mathrm{~h}$} \\
\hline & $(+)$ & $(-)$ & $(+)$ & $(-)$ & $(+)$ & $(-)$ & $(+)$ & $(-)$ \\
\hline Positive & 16 & 1 & 9 & 0 & 7 & 1 & 10 & 1 \\
\hline Negative & 37 & 0 & 2 & 0 & 0 & 0 & 0 & 0 \\
\hline Total & 53 & 1 & 11 & 0 & 7 & 1 & 10 & 1 \\
\hline
\end{tabular}


Sakurai et al ${ }^{1}$ from Osaka Medical School reported that $55.3 \%$ of the cases of foreign body aspiration showed radioluscent foreign body and the majority was a peanut. Mu et $\mathrm{al}^{4}$ in their studies during 7 years, found that $61 \%$ of the 378 cases of foreign body aspiration at the Shengyang Hospital in China aspirated a peanut and $60 \%$ showed abnormalities after more than 24 hours of aspiration. Esclamando et $\mathrm{al}^{3}$ reported that $67 \%$ of peanut aspiration cases will suffer lung complication after 24 hours. $4,5,6$

This study evaluated the role of chest X-ray examination in detecting a peanut in the airway. In this study lung abnormalities were found in $63.6 \%$ of cases, and then we analyzed the sensitivity and specificity of chest $\mathrm{X}$-ray as a diagnostic test. Diagnosis of aspirated peanut in children by chest X-ray examination did not show high sensitivity and specificity. Its sensitiviy was $53.1 \%$ and specificity was $33.3 \%$. The diagnostic sensitivity was increased according to the duration of aspiration, on the first day it was $30.2 \%$, on the second day it was $81.8 \%$ and on the third day it was $100 \%$.

Although plain chest $\mathrm{X}$-ray provide a good tool for studying pulmonary complication, fluoroscopy would be better in diagnosing a peanut in the tracheobronchial tree. ${ }^{3}$ Inspiratory and expiratory anteroposterior chest $\mathrm{X}$-ray are suggested, while on the contrary it is impossible to ask children in respiratory distress to do deep inspiration and expiration. Therefore bronchoscopy should substitute those mentioned procedures as a diagnostic tool in diagnosing a peanut in the tracheobronchial tree, within the first 24 hours of aspiration.
In conclusion, abnormal chest $\mathrm{X}$-rays were found in $29.62 \%$ of patients who aspirated a peanut within the first 24 hours, but abnormal chest X-ray was found in $86.6 \%$ of patients after 24 hours. Plain chest X-ray is better done in aspirated peanut in children which occur more than 24 hours. Bronchoscopy should be performed immediately in cases with airway obstruction that are warranted by history and physical examination.

\section{REFERENCES}

1. Sakurai K, Iwata S, Takasu A, Takeda N, Kaso R. Foreign bodies in the esophagus, trachea and bronchi handled in our clinic. In: Lee, Inouye T, Fukuda H, Sato T, editors. Recent advanoes in bronchology. Amsterdam: Elsevier, 1990:44950.

2. Iskandar N. Ingested and inhaled foreign body in Dr. Cipto Mangunkusumo Hospital Jakarta. Indones Med J Otorhinolaryngol 1994:311-8.

3. Mu L, Sun D, He P. Radiological diagnosis of aspirated foreign bodies in children. Review of 343 cases. J Laryngol Otol 1990;104:778-82.

4. Esclamando RM, Richardson MA. Laryngotracheal foreign bodies in children: A comparison with bronchial foreign bodies. Am J Dis Child 1987;14: 259-62.

5. Kirks DR. The pediatric ER chest: What every radiologist should know. In: Nash DCH, Petterson H, editors. Pediatric radiology. London: Merit Communications, 1992:154-71.

6. Healy GB. Management of tracheobronchial foreign bodies in children: An update. Ann Otol Rhinol Laryngol 1990; 90:889-92 